\title{
DNA binding, cleavage and cytotoxicity of a novel dimetallic Fe(III) triaza-cyclononane complex
}

\author{
Thaylan Pinheiro Araujo a,b ${ }^{\mathrm{a}}$ Valentina Gandin ${ }^{\mathrm{c}}$, Paul Kavanagh ${ }^{\mathrm{a}}$, Jeremy Phillip Braude ${ }^{\mathrm{c}}$, Luca Nodari ${ }^{\mathrm{d}}$, \\ Diego Montagner ${ }^{\mathrm{a}, *}$, Andrea Erxleben ${ }^{\mathrm{a}, *}$

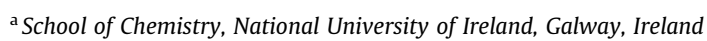 \\ ${ }^{\mathrm{b}}$ Department of Chemistry, Federal University of Maranhão, São Luís, Brazil \\ ' Dipartimento di Scienze del Farmaco, Universita' degli Studi di Padova, Padova, Italy \\ ${ }^{\mathrm{d}}$ Instituto di Chimica delle Superfici, CNR, Padova, Italy
}

\section{A R T I C L E I N F O}

\section{Article history:}

Received 8 December 2015

Received in revised form 9 February 2016

Accepted 13 February 2016

Available online 3 March 2016

\section{Keywords:}

Iron(III)

DNA cleavage

DNA binding

Cytotoxicity

\begin{abstract}
A B S T R A C T
A novel bimetallic Fe(III) complex with the bis(triaza-cyclononane) ligand 2,6-bis(1,4,7-triazacyclonon-1ylmethyl)-4-methylphenol (bcmp) is reported. $\left[\mathrm{Fe}_{2}\{\mathrm{bcmp}(-\mathrm{H})\}(\mu-\mathrm{OH}) \mathrm{Cl}_{2}\right] \mathrm{Cl}_{2}(2)$ contains two octahedral $\mathrm{Fe}(\mathrm{III})$ centers bound to the two triaza-cyclononane rings of bcmp. The coordination sphere is completed by one chlorine, one bridging phenolate oxygen and one bridging hydroxide group. The complex has been characterized by elemental analysis, Mössbauer spectroscopy, UV-Vis spectroscopy, pH potentiometric titration, ESI mass spectrometry and cyclic voltammetry. The complex hydrolyzes the DNA model bis (2,4-dinitrophenyl) phosphate (BDNPP) with a maximum activity a $\mathrm{pH}$ 7. Michaelis-Menten behavior is observed with $k_{\text {cat }}=3.56 \times 10^{-4} \mathrm{~s}^{-1}$ and $K_{\mathrm{m}}=0.56 \mathrm{mM}\left(\mathrm{pH} 7.0,40^{\circ} \mathrm{C}\right)$. The interaction of 2 with CT DNA was studied by electronic absorption spectroscopy and gel electrophoresis. Notably, the complex relaxes supercoiled pUC19 DNA into the nicked form at low micromolar concentration $(10 \mu \mathrm{M})$ in the presence of an external reducing agent (ascorbic acid). Finally, the in vitro antiproliferative activity of 2 was assessed on a panel of human cancer cell lines and results revealed that the complex exhibited a significant cytotoxic effects in particular versus colon LoVo cancer cells, wih $\mathrm{IC}_{50}$ value 2.5 times lower than that shown by the reference metallodrug cisplatin (3.54 versus $8.53 \mu \mathrm{M}$ ).
\end{abstract}

(c) 2016 Elsevier B.V. All rights reserved.

\section{Introduction}

Hydrolases are an important class of enzymes which catalyze hydrolysis reactions of several kinds of substrate [1] such as peptidases (peptide bonds) [2], ureases (urea) [3], purple acid phosphatase (phosphate monoesters) [4], phosphotriesterases (phosphotriesters) [5] and DNA/RNA polymerases (DNA and RNA) [6]. A common feature of most of the enzymes belonging to this important family is the presence of two metals in the active site, mainly $\mathrm{Mg}$ (II), Zn(II), Fe(II, III) and Mn(II) which can operate cooperatively. Several examples of bimetallic complexes are reported in the literature which are able to mimic the natural enzymes and catalyze hydrolysis reactions [7]. A precise spatial orientation of the two metal ions is a fundamental aspect to take into consideration while designing an artificial metallo-hydrolase. The two metal ions in the active site of an artificial hydrolase can be the same

\footnotetext{
* Corresponding authors.

E-mail addresses: diego.montagner@nuim.ie (D. Montagner), andrea. erxleben@nuigalway.ie (A. Erxleben).
}

(homo-nuclear complexes) or two different metals (hetero-nuclear complexes) or can have different oxidation states, mainly +2 and +3 . Our group is particularly interested in one class of this large family of enzymes, namely metallo-nucleases which are able to hydrolyze the phosphodiester bonds of DNA and RNA [8]. It is well known that the phosphate diester linkages in DNA are extremely resistant to spontaneous hydrolysis; the half-life for the hydrolysis of a phosphate diester bond in DNA at neutral $\mathrm{pH}$ and $25^{\circ} \mathrm{C}$ is more than hundreds of thousands years [9]. Such hydrolytic inertness, which ensures the preservation of the genetic information, makes DNA manipulation quite difficult. In vivo, DNA is manipulated by nucleases or restriction enzymes, which efficiently catalyze DNA scission in a sequence-specific manner [10]. Nucleases are able to accelerate the hydrolysis of the phosphate diester bonds in the DNA backbone up to $10^{16}$-fold, thus making the DNA manipulations that are essential for life possible. Artificial metallonucleases, metal complexes that catalyze phosphate diester hydrolysis and mimic the function of nucleases can be employed as biomimetic systems to elucidate the mechanisms of the natural enzymes. We recently reported two bimetallic complexes, a dinuclear $\mathrm{Cu}(\mathrm{II})$ 
and a dinuclear $\mathrm{Zn}$ (II) complex of 2,6-bis(1,4,7-triazacyclonon-1ylmethyl)-4-methylphenol (bcmp) which showed interesting biological properties such as DNA cleavage activity and in vitro cytotoxicity against different cancer cell lines [11,12]. These previous results triggered our interest in replacing $\mathrm{Cu}(\mathrm{II})$ and $\mathrm{Zn}(\mathrm{II})$ with a metal in a higher oxidation state such as Fe(III). We anticipated that the higher positive charge would lead to a stronger binding interaction with the negatively charged phosphate diester backbone of DNA and thus to a higher biological activity $[13,14]$. Furthermore, a recent paper published by Neves and co-workers showed that a bimetallic complex based on two Fe(III) ions is able to cleave DNA and catalyze the oxidation of catechol [15]. Herein we report the synthesis, full characterization, DNA interaction and cytotoxic properties of the new dinuclear $\mathrm{Fe}(\mathrm{III})$ complex $\left[\mathrm{Fe}_{2}\{\mathrm{bcmp}(-\mathrm{H})\}(\mu-\mathrm{OH}) \mathrm{Cl}_{2}\right] \mathrm{Cl}_{2}(\mathbf{2})$.

\section{Experimental}

\subsection{Materials and instruments}

$\mathrm{FeCl}_{3} \cdot 6 \mathrm{H}_{2} \mathrm{O}$ was purchased from TCI Europe. All the other chemicals and solvents were of analytical or spectroscopic grade, obtained from commercial sources and used without further purification. All the solvents were obtained from Apollo Scientific. Bcmp (1) [11] and bis(2,4-dinitrophenyl) phosphate (BDNPP) [16] were prepared following the literature procedures. UV-Vis measurements were carried out on a Varian Cary 50 scan spectrophotometer coupled to a Grant thermostatted water circulation bath. Elemental analyses (carbon, hydrogen and nitrogen) were performed with a PerkinElmer 2400 series II analyzer. ESI mass spectra were recorded in negative mode with a Waters LCT Premier XE Spectrometer. Room Temperature Mössbauer spectroscopy (RT-MS) was performed by using a conventional constant acceleration spectrometer, using a ${ }^{57} \mathrm{Fe}$ source, nominal strength $1850 \mathrm{MBq}$ in a Rh matrix.

\subsection{Synthesis}

\subsection{1. $\left[\mathrm{Fe}_{2}\{\mathrm{bcmp}(-\mathrm{H})\}(\mu-\mathrm{OH}) \mathrm{Cl}_{2}\right] \mathrm{Cl}_{2}$ (2)}

The complex was obtained by adding dropwise a methanolic solution ( $15 \mathrm{~mL}$ ) of $\mathrm{FeCl}_{3} \cdot 6 \mathrm{H}_{2} \mathrm{O}(750 \mathrm{mg}, 2.78 \mathrm{mmol})$ to a methanolic solution ( $5 \mathrm{~mL}$ ) of bcmp (532 $\mathrm{mg}, 1.37 \mathrm{mmol}$ ) and adjusting the $\mathrm{pH}$ to 5.8 with $\mathrm{NaOH}$. The clear, purple solution was stirred for $5 \mathrm{~h}$ at r.t. Addition of $75 \mathrm{~mL}$ of $\mathrm{Et}_{2} \mathrm{O}$ afforded the precipitation of a purple solid which was isolated by filtration, washed 3 times with $20 \mathrm{~mL}$ of diethyl ether and dried overnight under high-vacuum. Unfortunately all attempts to obtain crystals suitable for X-ray analysis failed. Yield: $675 \mathrm{mg}(1.02 \mathrm{mmol}, 75 \%)$. Anal. Calc. (\%) for $\mathrm{C}_{21} \mathrm{H}_{38} \mathrm{Cl}_{4} \mathrm{Fe}_{2} \mathrm{~N}_{6} \mathrm{O}_{2}$ : C, 38.21; $\mathrm{H}, 5.80 ; \mathrm{N}, 12.73$. Found: C, 38.84; $\mathrm{H}$, 5.45; N, 12.46. ESI-MS (-): $m / z \quad 657.04$ corresponding to $\left.\left[\mathrm{Fe}_{2}\{\mathrm{bcmp}(-\mathrm{H})\}(\mu-\mathrm{OH})(\mathrm{OH})_{2} \mathrm{Cl}_{3}\right)\right]^{-}$.

\subsection{Potentiometric titration}

An aqueous solution of $\mathbf{2}(1 \mathrm{mM}, 100 \mathrm{~mL})$ was titrated with a standardized $0.1 \mathrm{M} \mathrm{NaOH}$ solution at $25^{\circ} \mathrm{C}$. Water was boiled to remove any trace of $\mathrm{CO}_{2}$. The ionic strength was maintained at $0.1 \mathrm{M}$ with $\mathrm{KNO}_{3}$. $\mathrm{pH}$ values were measured with a Jenway 3510 pH meter fitted with a Refex Sensor Ltd. EC-1910-11 glass electrode. The program HYPERQUAD was used to calculate the deprotonation constant from the titration data [17].

\subsection{UV kinetic measurements}

The hydrolysis rates of BDNPP were measured by monitoring the increase in the visible absorbance at $400 \mathrm{~nm}$ due to the release of the 2,4-dinitrophenolate anion. Rate constants were obtained by the initial rate method ( $<5 \%$ conversion). Concentrations of $2,4-$ dinitrophenolate were calculated from the extinction coefficients $\left(12,100 \mathrm{M}^{-1} \mathrm{~cm}^{-1}\right)$. Concentrations were corrected for the degree of ionization of 2,4-dinitrophenol at the respective $\mathrm{pH}$ value using $\mathrm{p} K_{\mathrm{a}}(2,4$-dinitrophenol $)=4.0$ [18]. In a typical experiment $15 \mu \mathrm{L}$ of a freshly prepared BDNPP stock solution (5 mM in DMSO) was added to a solution of $2(1.5 \mathrm{~mL}, 0.25-5 \mathrm{mM})$ at $40^{\circ} \mathrm{C}$. The metal complex solutions were buffered with $50 \mathrm{mM}$ PIPBS ( $\mathrm{pH} 3.5-5)$, MES (pH 5-6.7), HEPES (pH 6.8-8.5) and CHES (pH 8.5-11.0). The ionic strength was maintained at $0.1 \mathrm{M}$ with $\mathrm{KNO}_{3}$. Hydrolysis rates for BDNPP have been corrected for the spontaneous hydrolysis of the substrate [16]. Kinetic runs were run in duplicate to give a reproducibility of $\pm 8 \%$.

Electronic spectra were recorded in $\mathrm{H}_{2} \mathrm{O}(5 \mathrm{mM})$ at different $\mathrm{pH}$ values (2.5, 5.0, 7.5 and 9.0) using the same buffer solution and the same ionic strength described before in this section.

\subsection{Mössbauer spectroscopy}

The RT Mössbauer spectrum was acquired on a sample of about $50 \mathrm{mg} 2$ mixed with vaseline. The hyperfine parameters isomer shift $(\delta)$, quadrupole splitting $(\Delta)$ and half linewidth at half maximum $\left(\Gamma_{1 / 2}\right)$, expressed in $\mathrm{mm} \mathrm{s}^{-1}$ were obtained by means of standard least-squares minimization techniques. The spectrum was fitted to Lorentzian line shapes with the minimum number of sextets and doublets. The isomeric shift is quoted relative to metallic iron at RT.

\subsection{Cyclic voltammetry}

Cyclic voltammograms were recorded using a PalmSens EmStat3+ potentiostat coupled to a single compartment electrochemical cell containing a $\mathrm{Ag} / \mathrm{AgCl}(3 \mathrm{M} \mathrm{KCl})$ reference electrode, a platinum wire counter electrode (Goodfellow, UK) and a glassy carbon working electrode (BAS). Voltammograms were recorded in pH 2.5, pH 5 (both $50 \mathrm{mM}$ citrate buffer), pH 7.5 (50 mM phosphate buffer) and pH 10.2 (50 mM CAPS) buffered solutions.

\subsection{DNA-binding experiments; UV-Vis absorption titration}

Absorption titration experiments were performed by maintaining a fixed CT-DNA concentration $(0.14 \mathrm{mM})$ in Tris- $\mathrm{HCl}$ buffer and increasing the concentration of $\mathbf{2}$ (producing reaction mixtures with varied mole ratio of complex to CT-DNA; range from 0.1 to 1). The reference solution was the corresponding Tris- $\mathrm{HCl}$ buffer solution. The sample solutions were scanned in the range 200-500 nm on a computer-controlled Varian Coulter DU 800 spectrophotometer.

\section{8. pUC19 DNA cleavage activity}

The DNA cleavage ability of $\mathbf{2}$ was evaluated by agarose gel electrophoresis. DNA plasmid pUC19 $(1 \mu \mathrm{g} / \mu \mathrm{L})$ was incubated with increasing concentration (range $10-100 \mu \mathrm{M}$ ) of 2 in Tris buffer (50 mM Tris, $18 \mathrm{mM} \mathrm{NaCl}, \mathrm{pH} 8.2$ ) in the absence and in the presence of an endogenous reductant (ascorbic acid) at $37^{\circ} \mathrm{C}$ for $3 \mathrm{~h}$ in the dark. The reaction was quenched by the addition of $3 \mu \mathrm{L}$ of loading buffer ( $0.25 \%$ bromophenol blue and $30 \%$ glycerol), and samples were loaded onto a $1 \%$ agarose gel in TBE buffer $(89 \mathrm{mM}$ Tris, $89 \mathrm{mM}$ boric acid, $2 \mathrm{mM}$ EDTA, pH 8.2). The gels were subjected to electrophoresis for $4 \mathrm{~h}$ at $50 \mathrm{~V}$, followed by staining with $0.5 \mu \mathrm{g} / \mathrm{mL}$ ethidium bromide overnight. Gel bands were visualized using a UV transilluminator and photographed using an Olympus digital camera. 


\subsection{Experiments with cultured human cells}

Compound 2 was dissolved in DMSO just before the experiment, and a calculated amount of drug solution was added to the cell growth medium to a final solvent concentration of $0.5 \%$, which had no detectable effect on cell killing. Cisplatin was dissolved in $0.9 \%$ sodium chloride solution. MTT (3-(4,5-dimethylthiazol-2yl)-2,5-diphenyltetrazolium bromide) and cisplatin were obtained from Sigma Chemical Co, St. Louis, USA.

\subsubsection{Cell cultures}

Human lung (A549) and pancreatic (BxPC3) carcinoma cell lines along with melanoma (A375) cells were obtained from American Type Culture Collection (ATCC, Rockville, MD). Human ovarian cancer cell lines 2008 were kindly provided by Prof. G. Marverti (Department of Biomedical Science of Modena University, Italy). Human cervical carcinoma cells A431 were kindly provided by Prof. F. Zunino (Division of Experimental Oncology B, Istituto Nazionale dei Tumori, Milan, Italy). LoVo human colon-carcinoma cell lines were kindly provided by Prof. F. Majone (Department of Biology of Padova University, Italy). Cell lines were maintained in the logarithmic phase at $37^{\circ} \mathrm{C}$ in a $5 \%$ carbon dioxide atmosphere using the following culture media containing $10 \%$ fetal calf serum (Euroclone, Milan, Italy), antibiotics (50 units/mL penicillin and $50 \mu \mathrm{g} / \mathrm{mL}$ streptomycin), and $2 \mathrm{mM}$ L-glutamine: (i) RPMI-1640 medium (Euroclone) for A431, 2008 and BxPC3 cells; (ii) F-12 HAM'S (Sigma Chemical Co.) for LoVo and A549 cells; (iii) DMEM (Sigma Chemical Co.) for A375 cells.

\subsubsection{MTT assay}

The growth inhibitory effect toward tumor cells was evaluated by means of MTT assay [19]. Briefly, (3-8) $\times 10^{3}$ cells/well, dependent upon the growth characteristics of the cell line, were seeded in 96-well microplates in growth medium $(100 \mu \mathrm{L})$. After $24 \mathrm{~h}$, the medium was removed and replaced with fresh media containing the compound to be studied at the appropriate concentration. Triplicate cultures were established for each treatment. After $72 \mathrm{~h}$, each well was treated with $10 \mu \mathrm{L}$ of a $5 \mathrm{mg} / \mathrm{mL}$ MTT saline solution, and following $5 \mathrm{~h}$ of incubation, $100 \mu \mathrm{L}$ of a sodium dodecylsulfate (SDS) solution in $\mathrm{HCl}(0.01 \mathrm{M})$ was added. After an overnight incubation, cell growth inhibition was detected by measuring the absorbance of each well at $570 \mathrm{~nm}$ using a Bio-Rad 680 microplate reader. The mean absorbance for each drug dose was expressed as a percentage of the control untreated well absorbance and plotted versus drug concentration. $\mathrm{IC}_{50}$ values, the drug concentrations that reduce the mean absorbance at $570 \mathrm{~nm}$ to $50 \%$ of those in the untreated control wells, were calculated by a four parameter logistic (4-PL) model.

\section{Results and discussion}

\subsection{Synthesis and spectroscopic characterization}

The di-iron(III) complex of composition $\left[\mathrm{Fe}_{2}\{\mathrm{bcmp}(-\mathrm{H})\}(\mu-\mathrm{OH})\right.$ $\mathrm{Cl}_{2} \mathrm{Cl}_{2}(\mathbf{2})$ has been obtained after addition of diethyl ether to a methanolic solution of $\mathrm{FeCl}_{3}$ and the ligand bcmp in a 2:1 ratio as shown in Chart 1. Unfortunately, several attempts to obtain crystals suitable for X-ray analysis, including exchanging the counter anion with perchlorate of hexcafluorophosphate, were unsuccessful. The solid has been characterized by elemental analysis, Mössbauer spectroscopy, UV-Vis spectroscopy, pH potentiometric titration, ESI mass spectrometry and cyclic voltammetry.

RT Mössbauer spectroscopic investigations confirmed the presence of only Fe(III) centers (Fig. 1). No signals attributable to $\mathrm{Fe}(\mathrm{II})$ species were detected. The best fitting was obtained by using

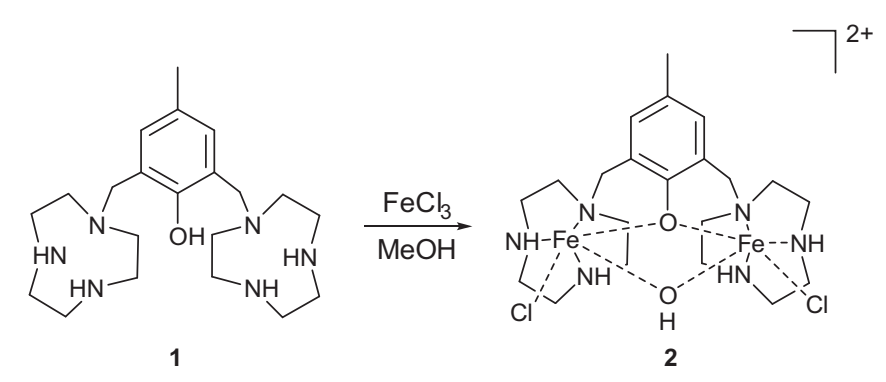

Chart 1. Synthetic route for the complex 2.

a single doublet. The parameters $(\delta: 0.36 \mathrm{~mm} / \mathrm{s}$ and $\Delta: 0.76 \mathrm{~mm} / \mathrm{s})$ are compatible with high spin octahedral $\mathrm{Fe}(\mathrm{III})(\delta: 0.36 \mathrm{~mm} / \mathrm{s}$ and $\Delta: 0.76 \mathrm{~mm} / \mathrm{s}$ ). The rather large $\Gamma_{1 / 2}$ value, $0.28 \mathrm{~mm} / \mathrm{s}$, is consistent with literature data for similar complexes [13,20-22]. On the basis of the experimental data the presence of two equivalent $\mathrm{Fe}(\mathrm{III})$ sites can be supposed.

In aqueous solution the two chlorido ligands are replaced by water ligands as confirmed by the ESI mass spectrum where the peak in the negative mode at $m / z=657.04$ corresponds to the species $\left\{\left[\mathrm{Fe}_{2}\{\mathrm{bcmp}(-\mathrm{H})\}(\mu-\mathrm{OH})(\mathrm{OH})_{2}\right]\left(\mathrm{Cl}_{3}\right)\right\}^{-}$(Fig. S1). The potentiometric pH titration of the complex was conducted in $\mathrm{H}_{2} \mathrm{O}$ and the results confirm the presence of two molecules of water bound to each Fe. From the titration curve it is clear that there are three deprotonation steps which require three equivalents of $\mathrm{NaOH}$ in the $\mathrm{pH}$ range between 2 and 11 (Fig. S2). The fitting of the titration data gave the three $\mathrm{p} K_{\mathrm{a}}$ values of $2.70 \pm 0.09,6.84 \pm 0.07$ and $8.32 \pm 0.09$. These values are in good agreement with those reported by Neves and co-workers for a similar di-iron complex (2.90, 6.25 and 7.56) and correspond to the deprotonation of the three molecules of water bound to the two Fe atoms [15]. In particular the first $\mathrm{p} K_{\mathrm{a} 1}$ (2.70) can be attributed to the deprotonation of the bridging $\mathrm{H}_{2} \mathrm{O}$ to form the complex $\left[\mathrm{Fe}_{2}\{\mathrm{bcmp}(-\mathrm{H})\}(\mu-\mathrm{OH})\right.$ $\left(\mathrm{OH}_{2}\right)_{2} \mathrm{JCl}_{4}(\mathbf{2 b}) ; \mathrm{p} K_{\mathrm{a} 2}$ corresponds to the deprotonation of one terminal $\mathrm{H}_{2} \mathrm{O}$ molecule to form $\left[\mathrm{Fe}_{2}\{\mathrm{bcmp}(-\mathrm{H})\}(\mu-\mathrm{OH})\left(\mathrm{OH}\left(\mathrm{OH}_{2}\right)\right] \mathrm{Cl}_{3}\right.$ (2c) and $\mathrm{p} K_{\mathrm{a} 3}$ to the deprotonation of the second terminal $\mathrm{H}_{2} \mathrm{O}$ (2d, Chart 2).

UV-Vis spectra of $\mathbf{2}$ in aqueous buffer solutions were recorded at different $\mathrm{pH}$ values (Fig. S3). In acidic solution ( $\mathrm{pH} 2.5$ ), when species $\mathbf{2 a}$ is predominant, the spectrum shows a defined band at $557 \mathrm{~nm}$ which can be assigned to a LMCT (Ligand to Metal Charge

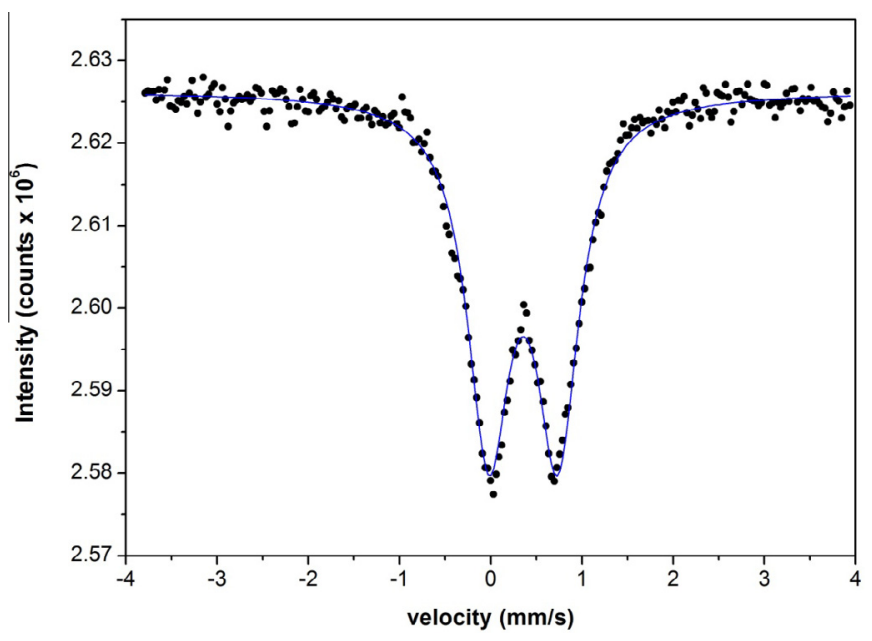

Fig. 1. RT Mössbauer spectrum of the di-Fe(III) complex. Black dots: experimental data, blue line: calculated spectrum. (For interpretation of the references to color in this figure legend, the reader is referred to the web version of this article.) 
Transfer) transition. The first deprotonation (from $\mathbf{2 a}$ to $\mathbf{2 b}$ ) leads to a very slight change in the electronic spectrum only $\left(\lambda_{\max }\right.$ at $\mathrm{pH} 5.0=550 \mathrm{~nm}$ ), but a remarkable shift can be observed after passing to $\mathbf{2 c}$ and to $\mathbf{2 d}$ when the $\lambda_{\max }$ moves to significantly lower wave lengths ( $\lambda_{\max }$ at $\mathrm{pH} 7.5$ and $9.0=535 \mathrm{~nm}$ and $490 \mathrm{~nm}$, respectively). This blue-shift ( $\Delta=22$ and $67 \mathrm{~nm}$, respectively) can be attributed to the fact that in $\mathbf{2 c}$ and $\mathbf{2 d}$ the Lewis acidity of the $\mathrm{Fe}(\mathrm{III})$ centers is lower and the $t_{2 \mathrm{~g}}$ orbitals of these species have higher energies with respect the $t_{2 g}$ orbitals of $\mathbf{2 a}$ and $\mathbf{2 b}$.

Voltammetric analysis of $\mathbf{2}$ was performed in order to evaluate the redox properties of the complex over a broad pH range. Fig. 2 shows cyclic voltammograms (CVs) recorded for 2 in aqueous media at $\mathrm{pH}$ values of $2.5,5,7.5$ and 10.2. At pH 2.5 the dimer complex is expected to be in the fully protonated form (species $\mathbf{2 a}$ ). At this $\mathrm{pH}$ the complex displays a cathodic peak potential (Epc) of $-0.182 \mathrm{~V}$ and an anodic peak potential (Epa) of $+0.84 \mathrm{~V}$ versus $\mathrm{Ag} / \mathrm{AgCl}$ indicative of an irreversible redox process [23]. The origin of the reduction and oxidation peaks is likely due to the reduction and subsequent oxidation of the Fe dimer metal center(s) as observed for analogous oxoiron [15], oxoruthenium [24] and oxomanganese $[25,26]$ dimer complexes. Epc peak potentials decrease linearly with increase of $\mathrm{pH}$ at a rate of $-0.067 \mathrm{~V}$ per $\mathrm{pH}$ unit (inset, Fig. 2) close to a theoretical value of $-0.059 \mathrm{~V}$ per $\mathrm{pH}$ unit predicted for a proton coupled or dependent electron transfer [27]. This reflects the successive electron coupled de-protonation of the bridging and terminal water ligands at $\mathrm{pH}$ values greater than $\mathrm{p} K_{\mathrm{a} 1}, \mathrm{p} K_{\mathrm{a} 2}$ and $\mathrm{p} K_{\mathrm{a} 3}$ in alignment with the potentiometric titration analysis.

\subsection{DNA binding}

The binding modes of $\mathbf{2}$ to DNA were characterized through electronic absorption titration and the representative UV-Vis spectrum in the presence of constant CT-DNA concentration is depicted in Fig. 3. Upon increasing the complex/CT-DNA molar ratio $(r)$ from 0.1 to 1 , an increase in the absorption intensities (hyperchromism) was observed. Hypochromism can result from a contraction of DNA helix axis as well as from a change in conformation of the DNA. However, our results clearly showed that no change in the position of the absorption bands of the complex in the presence of DNA occurred, thus suggesting the possibility of electrostatic and

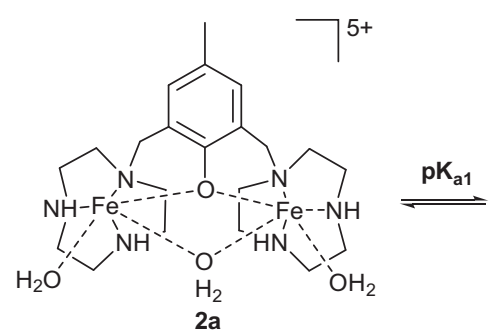

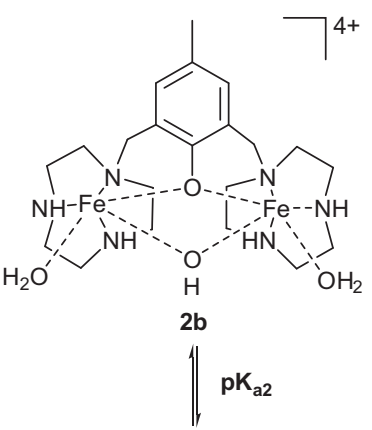

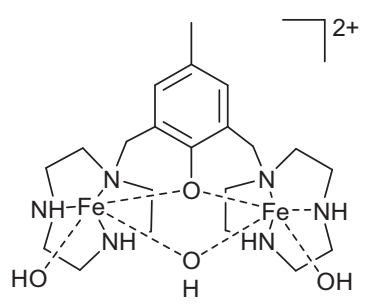
2d

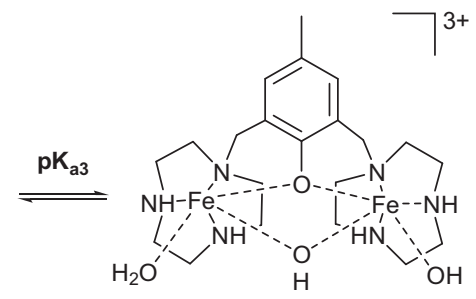

2c
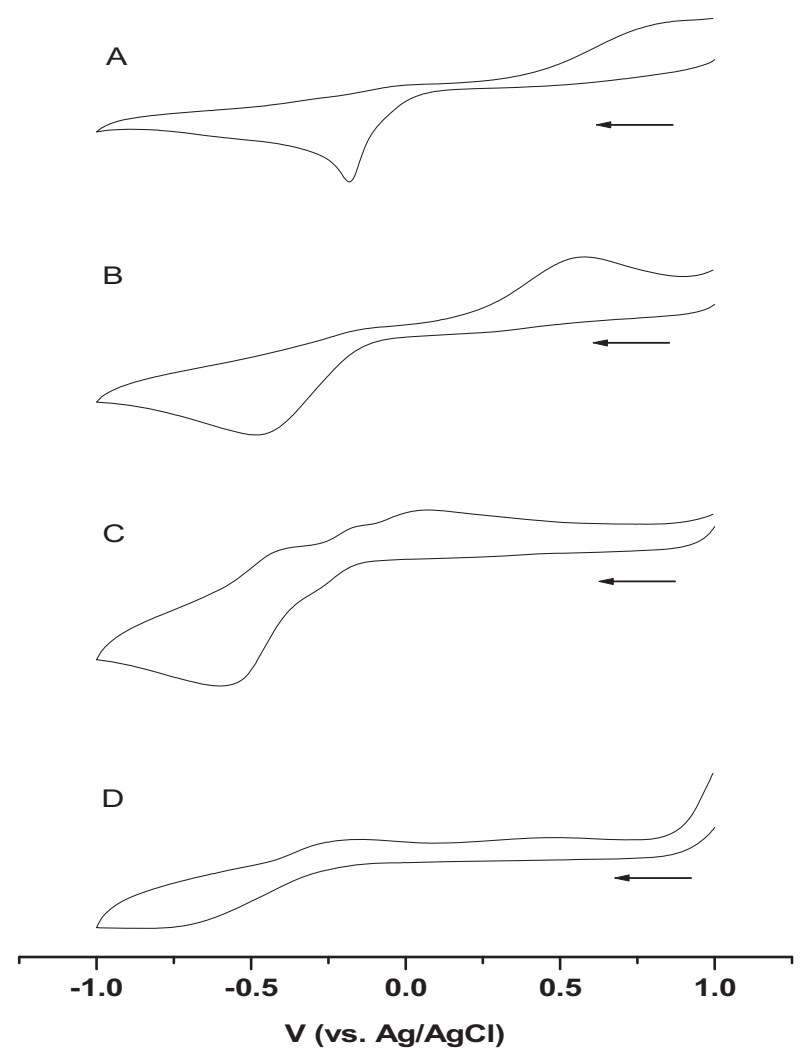

Fig. 2. Cyclic voltammograms of 2 recorded in pH 2.5 (A), pH 5 (B), pH 7.5 (C) and pH 10.2 (D) aqueous buffer solutions at a glassy carbon electrode. Arrows indicate direction of scan; anodic current positive, scan rate: $0.1 \mathrm{~V} \mathrm{~s}^{-1}$. Inset: Pourbaix plot of cathodic peak potentials (Epc) against $\mathrm{pH}$.

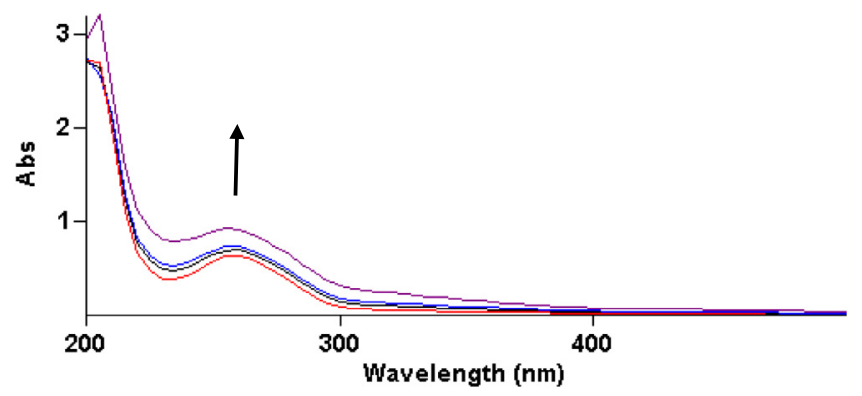

Fig. 3. Spectra of solutions containing CT-DNA $(0.14 \mathrm{mM})$ and increasing concentrations of complex 2 in Tris-HCl buffer, $\mathrm{pH} 8.1$.

groove (surface) binding of the metal complex outside the DNA helix, either in the major or minor groove. In particular, we can speculate that the hyperchromic effect could arise due to the non-covalent, electrostatic interaction between the positively charged complex moiety with extended hydrophobic region or surfaces and the negatively charged phosphate backbone of the double helix CT-DNA, thereby causing a contraction and an overall change of the secondary structure of DNA. In tris- $\mathrm{HCl}$ buffer $(\mathrm{pH}$ 8.1) the complex has an overall charge of $3+$.

\subsection{DNA cleavage and phosphate diester hydrolysis (BDNPP)}

The DNA cleavage activity of the complex was monitored by agarose gel electrophoresis using supercoiled pUC19 plasmid DNA. The cleavage ability was measured as the conversion of DNA

Chart 2. Proposed equilibria of complex 2. 
from the supercoiled form (SC, form I) of pUC19 plasmid DNA to the nicked-circular form (NC, form II). SC pUC19 DNA $(1 \mu \mathrm{g} / \mathrm{mL})$ was incubated with increasing complex concentrations (range 10$100 \mu \mathrm{M}$ ) for $3 \mathrm{~h}$ in the absence and in the presence of an endogenous reductant (ascorbic acid, $0.5 \mathrm{mM}$ ). Fig. S4 shows representative gel electrophoresis patterns resulting from the incubation of SC-DNA with 10 and $100 \mu \mathrm{M}$ solutions of the complex with and without ascorbic acid. As shown in Fig. S4, no prominent DNA cleavage was observed for the complex in the absence of ascorbic acid (lane 2 and 3). Conversely, treatment with complex 2 in combination with the reductant resulted in a concentration-dependent cleavage of DNA. Under this condition, even at the lowest concentration (lane 4), the complex was able to convert SC-DNA into the NC form, whereas at $100 \mu \mathrm{M}$ (lane 5), it cleaved DNA completely (absence of the SC form). Ascorbic acid is a typical reducing agent that is used to reduce $\mathrm{Fe}(\mathrm{III})$ to $\mathrm{Fe}(\mathrm{II})$ which is then responsible for the oxidative cleavage of DNA probably via ROS formation.

Complex 2 mediates oxidative cleavage of DNA as most Fe(III) complexes [28], but a few examples of Ferric complexes that hydrolyze DNA have been reported as well [29-32]. Therefore, we thought it of interest to explore the potential of $\mathbf{2}$ to mediate phosphate ester hydrolysis using BDNPP (bis(2,4-dinitrophenyl) phosphate) which is a widely used model for the phosphodiester linkages in DNA. 2-mediated BDNPP hydrolysis was monitored by following the increase in the visible absorbance at $400 \mathrm{~nm}$ because of the release of 2,4-dinitrophenolate. The dependence of the reaction rate of BDNPP cleavage on the $\mathrm{pH}$ value in the presence of $\mathbf{2}$ was studied over the $\mathrm{pH}$ range $4.0-10.0$. The plot of the pseudo-firstorder rate constants versus $\mathrm{pH}$ (Fig. 4) revealed a bell shaped profile with a maximum value at $\mathrm{pH} 7.0$, i.e. close to the midpoint between $\mathrm{p} K_{\mathrm{a} 2}$ and $\mathrm{p} K_{\mathrm{a} 3}$ ( $\mathrm{pH}$ 6.91). This behavior is completely different from the analogs $\mathrm{Zn}_{2}$ and $\mathrm{Cu}_{2}$ complexes reported by us which showed sigmoidal curves $[11,12]$. The dependence of the hydrolysis rate on the concentration of the Fe complex $\left(\mathrm{pH} \mathrm{7.0,40}{ }^{\circ} \mathrm{C}\right)$ is displayed in Fig. 5. The plot of the initial rate $\mathrm{v}_{0}$ versus complex concentration revealed saturation kinetics and the linear Lineweaver-Burk plot (inset, Fig. 5) indicated Michaelis-Menten behavior with the formation of a kinetically active complex-substrate intermediate. From the Lineweaver-Burk plot, the hydrolysis rate of the bound substrate, $k_{\text {cat }}=3.56 \times 10^{-4} \mathrm{~s}^{-1}$, and the substrate binding constant, $K_{\mathrm{m}}=0.56 \mathrm{mM}$, were obtained. These values indicate a good catalytic activity and a moderate binding affinity of BDNPP for $\mathbf{2}$ and are in line with other dinuclear Fe(III) complexes reported in the literature [29-31]. Based on the kinetic data we propose the mechanism shown in Chart 3 for the hydrolysis of BDNPP by 2 . The

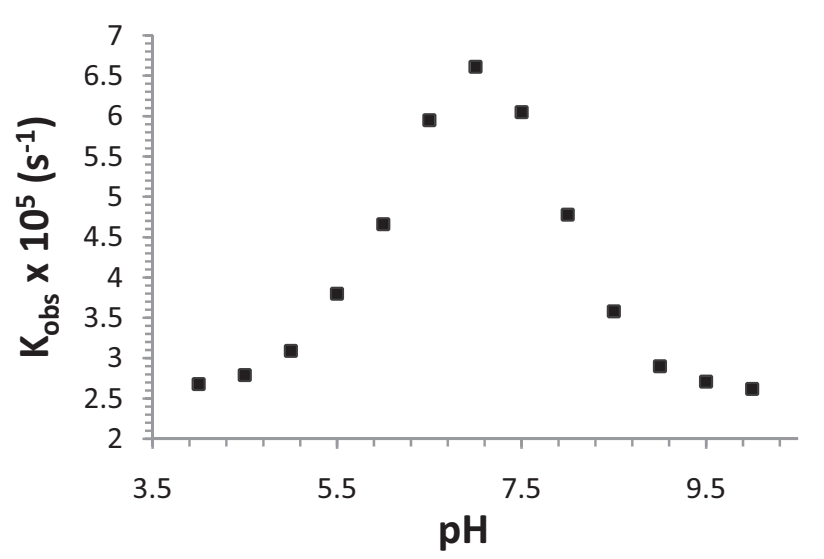

Fig. 4. Rate-pH profile for the cleavage of $\operatorname{BDNPP}\left(5 \times 10^{-5} \mathrm{M}\right)$ in the presence of 2

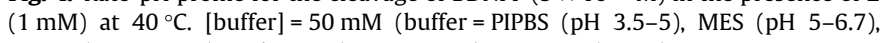
HEPES (pH 6.8-8.5), and CHES ( $\mathrm{pH} 8.5-10.0) ; I=0.1 \mathrm{M}\left(\mathrm{KNO}_{3}\right)$.

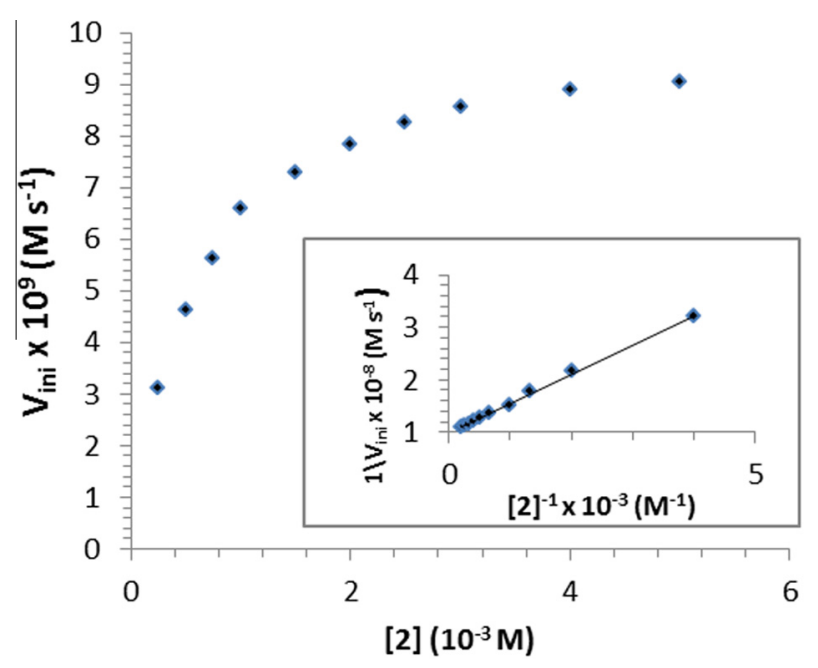

Fig. 5. Dependence of the hydrolysis rate of BDNPP $\left(5 \times 10^{-5} \mathrm{M}\right)$ on the concentration of 2 at $\mathrm{pH} 7.0\left(50 \mathrm{mM}\right.$ HEPES) and $40^{\circ} \mathrm{C} . I=0.1 \mathrm{M}\left(\mathrm{KNO}_{3}\right)$. Inset: The Lineweaver-Burk double-reciprocal plot.

maximum in the rate-pH profile coincides with the $\mathrm{pH}$ value at which the concentration of $\mathbf{2 c}$ is highest, suggesting that $\mathbf{2 c}$ is the active species. The water ligand in $\mathbf{2} \mathbf{c}$ is the labile site where the phosphate diester can bind to the $\mathrm{Fe}_{2}$ complex, while the hydroxido ligand on the second Fe acts as the nucleophile.

\subsection{Cytotoxicity}

The cytotoxic properties of $\mathbf{2}$ were evaluated against a panel of human tumor cell lines containing examples of colorectal (LoVo), pancreatic (BxPC3), cervical (A431), lung (A549), and ovarian (2008) cancers as well as of melanoma (A375). For comparison purposes, the cytotoxicity of cisplatin, the most widely used metal-based anticancer drug, was evaluated under the same experimental conditions. $\mathrm{IC}_{50}$ values, calculated from the dose-survival curves obtained after $72 \mathrm{~h}$ of drug treatment from the MTT assay, are shown in Table 1. Although on average the cytotoxic potency shown by $\mathbf{2}$ was lower than that of cisplatin against four of the tested tumor cell lines belonging to the in-house cell panel, the dimetallic Fe(III) complex retained a significant in vitro antitumor activity against LoVo cancer cells and against A375 melanoma cells. Remarkably, the $\mathrm{IC}_{50}$ values calculated for $\mathbf{2}$ in colon cancer cells was roughly 2.5 times lower than that of the reference metallodrug cisplatin whereas against melanoma cells the toxicity was comparable to that of cisplatin.

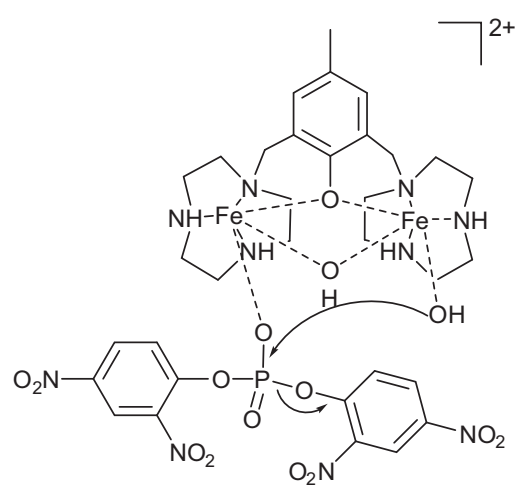

Chart 3. Proposed mechanism of hydrolysis of BDNPP. 
Table 1

Cytotoxic activity. Cells $\left(3-5 \times 10^{4} \mathrm{ml}^{-1}\right)$ were treated for $72 \mathrm{~h}$ with increasing concentrations of $\mathbf{2}$ or cisplatin. Cell viability was evaluated by means of MTT test. $\mathrm{IC}_{50}$ values were calculated by the dose-response curves by means of four parameter logistic model $(p<0.05)$. SD = standard deviation.

\begin{tabular}{lrr}
\hline Cell lines & \multicolumn{1}{c}{$\mathrm{IC}_{50},[\mu \mathrm{M}] \pm \mathrm{SD}$} \\
\cline { 2 - 3 } & \multicolumn{1}{c}{ Cisplatin } & \multicolumn{1}{c}{$\mathbf{2}$} \\
\hline LoVo & $8.53 \pm 1.14$ & $3.54 \pm 0.97$ \\
BxPC3 & $11.13 \pm 2.36$ & $14.09 \pm 2.75$ \\
A431 & $1.65 \pm 0.51$ & $2.01 \pm 0.77$ \\
A375 & $1.89 \pm 0.85$ & $25.61 \pm 4.48$ \\
A549 & $9.98 \pm 2.86$ & $13.55 \pm 7.81$ \\
2008 & $2.22 \pm 1.03$ & \\
\hline
\end{tabular}

\section{Conclusions}

$\left[\mathrm{Fe}_{2}\{\mathrm{bcmp}(-\mathrm{H})\}(\mu-\mathrm{OH}) \mathrm{Cl}_{2}\right] \mathrm{Cl}_{2}$ is a novel dinuclear $\mathrm{Fe}(\mathrm{III})$ complex which interacts with CT-DNA via electrostatic interaction between the high positive charge (at $\mathrm{pH} 8.1$, tris- $\mathrm{HCl}$ buffer, 2 is $3+$ ) and the negative charges of the DNA phosphate groups. The complex oxidatively cleaves pUC19 plasmid DNA in the presence of ascorbic acid while hydrolytic cleavage is observed with the model DNA phosphate ester BDNPP. Cytotoxicity studies revealed an interesting activity in particular against a human colon cancer cell line. Taken together, these results suggest that the in vitro antitumor activity of $\mathbf{2}$ could be attributed to its DNA binding ability, thus supporting the hypothesis that the molecular mechanism and cytotoxic potential of $\left[\mathrm{Fe}_{2}\{\mathrm{bcmp}(-\mathrm{H})\}(\mu-\mathrm{OH}) \mathrm{Cl}_{2}\right] \mathrm{Cl}_{2}$, is related to DNA cleavage ability. However, further in-cell experiments are needed, in order to fully characterize molecular determinants accounting for its antitumor potential.

\section{Acknowledgments}

Financial support from the European Commission (Marie Curie FP7-IEF to D.M.); the University of Padova (Grants 60A04-0443, 60A04-3189 and 60A04-4015/15) and Science Foundation Ireland are gratefully acknowledged. T. P. A. thanks the Brazilian Government and CAPES for a Science Without Border Scholarship. Prof. Michael J. Hynes, School of Chemistry, NUI Galway, is thanked for the calculation of the deprotonation constants from the titration data.

\section{Appendix A. Supplementary material}

Supplementary data associated with this article can be found, in the online version, at http://dx.doi.org/10.1016/j.ica.2016.02.044.

\section{References}

[1] D.E. Wilcox, Chem. Rev. 96 (1996) 273

[2] M. Matsui, J.H. Fowler, L.L. Walling, Biol. Chem. 387 (2006) 1535.

[3] P.A. Karplus, M.A. Pearson, R.P. Hausinger, J. Am. Chem. Soc. 126 (2004) 3714.

[4] N. Mitic, S.J. Smoth, A. Neves, L.W. Guddat, L.R. Gahan, G. Schenk, Chem. Rev. 106 (2006) 3338

[5] J. Weston, Chem. Rev. 105 (2005) 2151

[6] W. Yang, J.Y. Lee, M. Novotny, Mol. Cell 22 (2006) 5.

[7] E.L. Hegg, J.N. Burstyn, Coord. Chem. Rev. 173 (1998) 133.

[8] F. Mancin, P. Scrimin, P. Tecilla, U. Tonellato, Chem. Commun. (2005) 2540.

[9] N.H. Williams, B. Takasaki, M. Wall, J. Chin, Acc. Chem. Res. 32 (1999) 485.

[10] I. Bertini, H.B. Gray, S.J. Lippard, J.S. Valentine, Eds.; University Science Books, Mill Valley, 1994, pp. 455.

[11] D. Montagner, V. Gandin, C. Marzano, A. Erxleben, J. Inorg. Biochem. 145 (2015) 101.

[12] D. Montagner, V. Gandin, C. Marzano, A. Erxleben, Eur. J. Inorg. Chem. 25 (2014) 4084

[13] M. Jarenmark, M. Haukka, S. Demeshko, F. Tuczek, L. Zuppiroli, F. Meyer, E. Nordlander, Inorg. Chem. 50 (2011) 3866.

[14] H. Liu, Y.Y. Kou, L. Feng, D.D. Li, C.Y. Gao, J.L. Tian, J.Y. Zhang, S.P. Yan, Appl. Organomet. Chem. 24 (2010) 636.

[15] T.P. Camargo, F.F. Maia, C. Chaves, B. De Souza, A.J. Bortoluzzi, N. Castilho, T. Bortolotto, H. Terenzi, E.E. Castellano, W. Haase, Z. Tomkowicz, R.A. Peralta, A Neves, J. Inorg. Biochem. 146 (2015) 77.

[16] C.A. Bunton, S.J. Farber, J. Org. Chem. 34 (1969) 767.

[17] P. Gans, A. Sabatini, A. Vacca, Talanta 143 (1996) 1739.

[18] A.E. Martell, R.M. Smith, Critical Stability Constants, Plenum press, New York, 1977.

[19] M.C. Alley, D.A. Scudiero, A. Monks, M.L. Hursey, M.J. Czerwinski, D. Fine, B.J. Abbott, J.G. Mayo, R.H. Shoemaker, M.R. Boyd, Cancer Res. 48 (1988) 589.

[20] A. Neves, M.A. de Brito, I. Vencato, V. Drago, K. Griesar, W. Haase, Inorg. Chem. 35 (1996) 2360.

[21] J.A. Hartman, R.L. Rardin, P. Chaudhuri, K. Pohl, K. Wieghardt, B. Nuber, J. Weiss, G.C. Papaefthymiou, R.B. Frankel, S. Lippard, J. Am. Chem. Soc. 109 (1987) 7387.

[22] R.F. Moreira, E.Y. Tshuva, S. Lippard, Inorg. Chem. 43 (2004) 4427.

[23] A.J. Bard, L.R. Faulkner, Electrochemical Methods: Fundamentals and Applications, 2nd ed., Wiley, New York, 2001.

[24] A. Llobet, P. Doppelt, T.J. Meyer, Inorg. Chem. 27 (1988) 514.

[25] H.H. Thorp, J.E. Sarneski, G.W. Brudwig, R.H. Crabtree, J. Am. Chem. Soc. 111 (1989) 9249.

[26] R. Manchanda, H.H. Thorp, G.W. Brudvig, R.H. Crabtree, Inorg. Chem. 30 (1991) 494.

[27] M.H.V. Huynh, T.J. Meyer, Chem. Rev. 107 (2007) 5004.

[28] F.B.A. El Amrani, L. Perello, J.A. Real, M. Gonzales-Alvarez, G. Alzuet, J. Borras, S. Garcia-Granda, J. Montejo-Bernardo, J. Inorg. Biochem. 100 (2006) 1208.

[29] A. Neves, H. Terenzi, R. Rosmari, A. Horn, B. Szpoganicz, J. Sugai, Inorg. Chem. Commun. 4 (2001) 388.

[30] S.J. Smith, R.A. Peralta, R. Jovito, A. Horn, A.J. Bortoluzzi, C.J. Noble, G.R. Hanson, R. Stranger, V. Jayaratne, G. Cavigliasso, L.R. Gahan, G. Schenk, O.R. Nascimento, A. Cavalett, T. Bortolotto, G. Razzera, H. Terenzi, A. Neves, M.J. Riley, Inorg. Chem. 51 (2012) 2065.

[31] A. Neves, A.J. Bortoluzzi, R. Jovito, R.A. Peralta, B. De Souza, B. Szpoganicz, A.C. Joussef, H. Terenzi, P.C. Severino, F.L. Fischer, G. Schenk, M.J. Riley, S.J. Smith, L. R. Grahan, J. Braz. Chem. Soc. 21 (2010) 1201.

[32] L.M. Schnaith, R.S. Hanson, L. Que Jr., Proc. Natl. Acad. Sci. U.S.A. 91 (1994) 569. 